\title{
Short communication: Detection of yeast DNA in omasal digesta of dairy cows consuming dried distillers grains and solubles
}

\author{
E. Castillo-Lopez, P. J. Kononoff, ${ }^{1}$ and J. L. Miner \\ Department of Animal Science, University of Nebraska-Lincoln, Lincoln 68583-0908
}

\begin{abstract}
Purine analysis is widely used to estimate microbial crude protein (MCP) flow, and the method assumes that all purines contained in feed are degraded in the rumen and that purines detected are of microbial origin. The objectives of our experiment were (1) to determine if DNA from yeast (Saccharomyces cerevisiae) contained in dried distillers grains and solubles (DDGS) escapes degradation in the rumen and (2) to estimate the proportion of yeast DNA compared with total bacterial DNA in omasal samples. Two ruminally fistulated Holstein dairy cows averaging $649 \mathrm{~kg}$ (SD $=42.0)$ and $126 \mathrm{~d}$ in milk $(\mathrm{SD}=28.9)$ were fed in a crossover design during 2 periods of $21 \mathrm{~d}$ each. Treatments were (1) control, a total mixed ration (TMR) not containing DDGS and (2) a DDGS-based diet, a TMR in which DDGS were included at $30 \%$ of diet dry matter (DM). On d 20 and 21 at 0400 and 1600 $\mathrm{h}$, omasal digesta samples were collected via a ruminal cannula, and DNA was extracted from each sample in duplicate. The DNA samples were subjected to a realtime PCR assay to detect the presence of DNA from yeast. Forward and reverse primers and a probe were designed to target a DNA segment contained on the second chromosome of Saccharomyces cerevisiae. Realtime PCR amplification curves indicated the presence of yeast DNA in samples from both treatments. Specifically, the estimate of relative abundance of yeast DNA from digesta samples collected from animals consuming the diet containing DDGS was $9.46 \pm 0.67 / \mathrm{g}$ of DM and was significantly higher than that from animals consuming no DDGS, which was observed to be 0.091 $\pm 0.67 / \mathrm{g}$ of DM. Omasal samples were also analyzed for total bacterial DNA. Primers and a probe were designed from DNA encoding part of the 16S rRNA. When the DDGS-based diet was fed, the relative abundance of total bacterial DNA tended to increase from 610 to $626 \pm 3.82 / \mathrm{g}$ of DM. Results suggest that yeast DNA is detected in the omasum and this is increased
\end{abstract}

Received March 29, 2010.

Accepted August 26, 2010.

${ }^{1}$ Corresponding author: pkononoff2@unlnotes.unl.edu when cows consume DDGS but it does not represent a significant proportion of total microbial DNA in the omasal digesta samples.

Key words: dried distillers grains and solubles, realtime PCR, purines, yeast DNA

Rumen microbial crude protein (MCP) represents an important supply of peptides and amino acids to the host animal (Lapierre et al., 2006). Estimation of MCP has been carried out by a variety of methods including purine analysis (Zinn and Owens, 1986), diamino pumelic acid measurement (Weller et al., 1958), measurement of RNA (McAllan and Smith, 1969), and real-time PCR to target specific gene sequences in protozoa (Sylvester et al., 2005). Of the methods currently available to estimate rumen microbial protein, purine analysis has been the most widely used. If the DNA from yeast is not degraded in the rumen, then it would supply nucleic acids and purines to the lower gastrointestinal tract. Analytically, MCP might be overestimated if one uses the measure of purines as an indirect estimate of MCP (Zinn and Owens, 1986; Obispo and Dehority, 1999).

Real-time PCR may be used for the detection and quantification of microbial populations (Yu et al., 2005). The technique allows detection of microbial DNA, and thus may be used to indicate the presence of a target microorganism or group of microorganisms (Nadkarni et al., 2002). Real-time PCR uses a fluorescence probe in addition to 2 primers, which allow reliable detection of a target DNA (Wellinghausen et al., 2001). The objectives of this experiment were to determine if DNA from yeast (Saccharomyces cerevisiae) contained in dried distillers grains and solubles (DDGS) can be detected in omasal digesta and to determine the proportion of yeast DNA compared with bacterial DNA in these samples.

Two lactating ruminally fistulated Holstein cows of 619.6 and $679.5 \mathrm{~kg}$ of BW, 106 and 147 DIM, and producing 44.6 and $40.0 \mathrm{~kg}$ of milk, respectively, were used. Animals were fed 1 of 2 rations that differed in the proportion of DDGS included: either 0 (control) or $29.2 \%$ (DDGS diet) of the diet DM. Table 1 lists the ingredients and analyzed chemical composition of the 
Table 1. Ingredients and average chemical composition (and standard deviation) of experimental treatments providing 2 levels of DDGS (DM basis)

\begin{tabular}{|c|c|c|}
\hline \multirow[b]{2}{*}{ Item } & \multicolumn{2}{|c|}{ Treatment $^{1}$} \\
\hline & Control & DDGS added \\
\hline \multicolumn{3}{|l|}{ Ingredient, $\%$ of DM } \\
\hline Corn silage & 40.2 & 40.7 \\
\hline $\mathrm{DDGS}^{2}$ & - & 29.2 \\
\hline Ground corn & 20.1 & 6.3 \\
\hline Alfalfa haylage & 10.4 & 4.4 \\
\hline Brome hay & 4.39 & 3.55 \\
\hline Soybean meal & 12.5 & 4.39 \\
\hline Soybean hulls & 4.18 & 4.18 \\
\hline Soy Pass ${ }^{3}$ & 4.18 & 3.45 \\
\hline Magnesium oxide & 0.33 & 0.15 \\
\hline Trace mineral $^{4}$ & 0.10 & 0.10 \\
\hline Limestone & 1.25 & 2.09 \\
\hline Salt & 0.42 & 0.42 \\
\hline Vitamin $\mathrm{ADE}^{5}$ & 0.13 & 0.13 \\
\hline Sodium bicarbonate & 0.97 & 0.94 \\
\hline Dicalcium phosphate & 0.84 & - \\
\hline \multicolumn{3}{|c|}{ Chemical composition, \% } \\
\hline $\mathrm{CP}$ & $15.0(0.17)$ & $17.5(0.38)$ \\
\hline NDF & $29.7(0.14)$ & $37.1(0.55)$ \\
\hline Starch & $26.6(1.13)$ & $17.3(2.05)$ \\
\hline Ether extract & $2.0(0.18)$ & $5.5(0.27)$ \\
\hline $\mathrm{NFC}^{6}$ & $43.7(0.98)$ & $30.0(1.54)$ \\
\hline
\end{tabular}

${ }^{1}$ Control $=0 \%$ DM of DDGS; DDGS added $=29.2 \%$ DM of DDGS.

${ }^{2}$ Dakota Gold dried distillers grains plus solubles (Poet Nutrition, Sioux Falls, SD).

${ }^{3}$ LignoTech (Overland Park, KS).

${ }^{4}$ Formulated to provide $0.96 \% \mathrm{Ca}, 0.48 \% \mathrm{P}, 0.38 \% \mathrm{Mg}$, and $1.35 \% \mathrm{~K}$.

${ }^{5}$ Formulated to contain $7.231 \mathrm{kIU} / \mathrm{kg}$ of vitamin A, $1.829 \mathrm{kIU} / \mathrm{kg}$ of vitamin $\mathrm{D}$, and $58.13 \mathrm{kIU} / \mathrm{kg}$ of vitamin $\mathrm{E}$.

${ }^{6} \mathrm{NFC}$ calculated by difference: $100-(\% \mathrm{NDF}+\% \mathrm{CP}+\%$ Fat $+\%$ Ash).

experimental rations. To include the DDGS, a portion of ground corn, alfalfa haylage, brome hay, and soybean meal was replaced from the control ration.

Total mixed rations were sampled on the last $2 \mathrm{~d}$ of each period. Feed samples were dried for $48 \mathrm{~h}$ at $55^{\circ} \mathrm{C}$ in a forced air oven, ground to pass through a 1-mm screen (Wiley mill, Arthur A. Thomas Co., Philadelphia, PA), and composited by sample for each period. Feed samples were analyzed for DM (AOAC, 2000), N (Leco, FP-528, Leco Corp., St. Joseph, MI), and NDF (Ankom Fiber Analyzer, Ankom Technology, Fairport, NY). Heat stable $\alpha$-amylase (A3306, Sigma Chemical Co., St. Louis, MO) was included in the NDF procedure $(100 \mu \mathrm{L}$ per $0.50 \mathrm{~g}$ of sample). The TMR were analyzed for starch (Total Starch Assay, Megazyme International, Bray, Ireland) and ether extract (AOAC, 2000). Additionally, the TMR were analyzed for yeast DNA by real-time PCR.

Experimental measures were carried out in 2 periods of $21 \mathrm{~d}$ each. On d 20 and 21 of each period, omasal samples were collected twice daily at 0400 and $1600 \mathrm{~h}$ according to the modified procedure of Huhtanen et al. (1997). The DNA was extracted in duplicate from wet omasal samples by the repeated bead beating plus column $(\mathrm{RBB}+\mathrm{C})$ method ( $\mathrm{Yu}$ and Morrison, 2004). Then, DNA samples collected were analyzed for yeast and total bacterial DNA.

\section{Primers and Probes for Yeast}

The forward and reverse primers and a dual-labeled probe were designed from part of the second chromosome of the yeast (Saccharomyces cerevisiae) genome. To design these oligonucleotides, the National Center of Biotechnology Information (NCBI) blast software (http://www.ncbi.nlm.nih.gov/) was used to verify that the DNA sequence belonged only to $S$. cerevisiae, so that it would not be cofounded by other related fungi species. The NCBI accession number of the targeted DNA amplicon is Y08934. The oligonucleotides were analyzed with the oligo analyzer of the integrated DNA technology (IDT) program (http://www.idtdna.com/ Home/Home.aspx) to verify whether those oligonucleotides were adequate for use in real-time PCR assays. The sequences were as follows: forward primer: $5^{\prime}$-cct gct aaa ctg cag ctt gac-3'; TaqMan probe: $5^{\prime}$-FAM/ctg cgg acc ctg cag tcc agc/TAMRA-3'; and reverse primer: $5^{\prime}$-cag cgt ttg cgt tcc atg ac-3'.

\section{Primers and Probes for Bacteria}

The forward and reverse primers and a dual-labeled probe were designed from DNA encoding part of the 16S rRNA (Yu et al., 2005). The NCBI accession number of the targeted DNA amplicon is FJ715623, with sequences as follows: forward primer: 5 '-act cct acg gga ggc agc ag-3'; TaqMan probe: 5'-FAM/tgc cag cag ccg cgg taa tac/TAMRA-3'; and reverse primer: $5^{\prime}$-gac tac cag ggt atc taa tcc- $3^{\prime}$.

The DNA samples were subjected to 10 -fold serial dilutions a total of 3 times. To carry out the real-time $\mathrm{PCR}, 8 \mu \mathrm{L}$ of DNA sample (initial concentration 12.1 $\mathrm{ng} / \mu \mathrm{L})$ was combined with $2.4 \mu \mathrm{L}$ of $10 \mu M$ forward primer, $2.4 \mu \mathrm{L}$ of $10 \mu \mathrm{M}$ reverse primer, $0.72 \mu \mathrm{L}$ of $10 \mu M$ TaqMan probe, $24 \mu \mathrm{L}$ of TaqMan Master Mix (Applied Biosystems, Foster City, CA), and $10.48 \mu \mathrm{L}$ of nanopure water. Each sample was run in duplicate in separate wells of the real-time PCR plate.

The DNA samples were subjected to real-time PCR using a 7900HT Fast Real-Time PCR System (Applied Biosystems); temperature cycling was as follows: stage 1: $50^{\circ} \mathrm{C}$ for $2 \mathrm{~min}$; stage $2: 95^{\circ} \mathrm{C}$ for $10 \mathrm{~min}$; stage $3: 45$ cycles alternating denaturation at $95^{\circ} \mathrm{C}$ for $15 \mathrm{~s}$ and annealing and polymerization at $60^{\circ} \mathrm{C}$ for $1 \mathrm{~min}$. 
To calculate the relative abundance of the targeted DNA amplicon, we estimated the DNA exponential amplification. In theory, DNA may be doubled during each PCR cycle, which means that exponential amplification would equal 2. However, DNA amplification is not $100 \%$ efficient. After subjecting DNA samples to the 10-fold serial dilutions and adding primers, probe, and TaqMan Master Mix, the dilution factor was estimated by dividing the initial DNA concentration by the final concentration. Then, the cycle thresholds (CT; number of cycles required to reach an amplification threshold) were plotted against the log of the dilution factor. The slope of the curve obtained was then used in the following equation: $\mathrm{E}=10^{(-1 / \text { slope })}$, where $\mathrm{E}$ is the exponential amplification and slope is the slope of the plot of CT against the log of dilution factor.

Once we estimated the exponential amplification, the relative abundance of the targeted DNA amplicon was calculated by using the following equation: Relative abundance $=1 /\left(\mathrm{E}^{\mathrm{CT}}\right)$, where relative abundance is the relative abundance of the targeted yeast DNA amplicon, $\mathrm{E}$ is the exponential amplification, and $\mathrm{CT}$ is the number of cycles at threshold.

The equation used for the estimation of the relative abundance was derived as follows:

Final amount of target DNA amplicon $=$ initial amount of target DNA amplicon $\times \mathrm{E}^{\mathrm{CT}}$,

$$
\begin{gathered}
\text { Initial amount of target DNA amplicon }= \\
\text { final amount of target DNA amplicon } /\left(\mathrm{E}^{\mathrm{CT}}\right) \text {. }
\end{gathered}
$$

Then, we replaced the final amount of target DNA amplicon with a constant (1), obtaining the final equation: Initial amount of target DNA amplicon (relative abundance $)=1 /\left(\mathrm{E}^{\mathrm{CT}}\right)$.

The data collected were analyzed using the MIXED procedure of SAS (SAS Institute, 2004) as a $2 \times 2$ crossover design and assuming treatment, period, day, and sampling time as fixed effects and cow as a random effect. The PDIFF option of SAS was used to generate least squares means.

The real-time PCR amplification curves indicated the presence of yeast DNA in omasal digesta samples. All samples were run in the same plate, and a nontemplate control was included. Three sets of curves originated because each sample was subjected to 10 -fold serial dilutions a total of 3 times. When cows were fed DDGS, the first amplification curve crossed the threshold at approximately 29 cycles. However, when the cows were fed the control diet, the first amplification curve crossed the threshold at almost 36 cycles. This suggests that

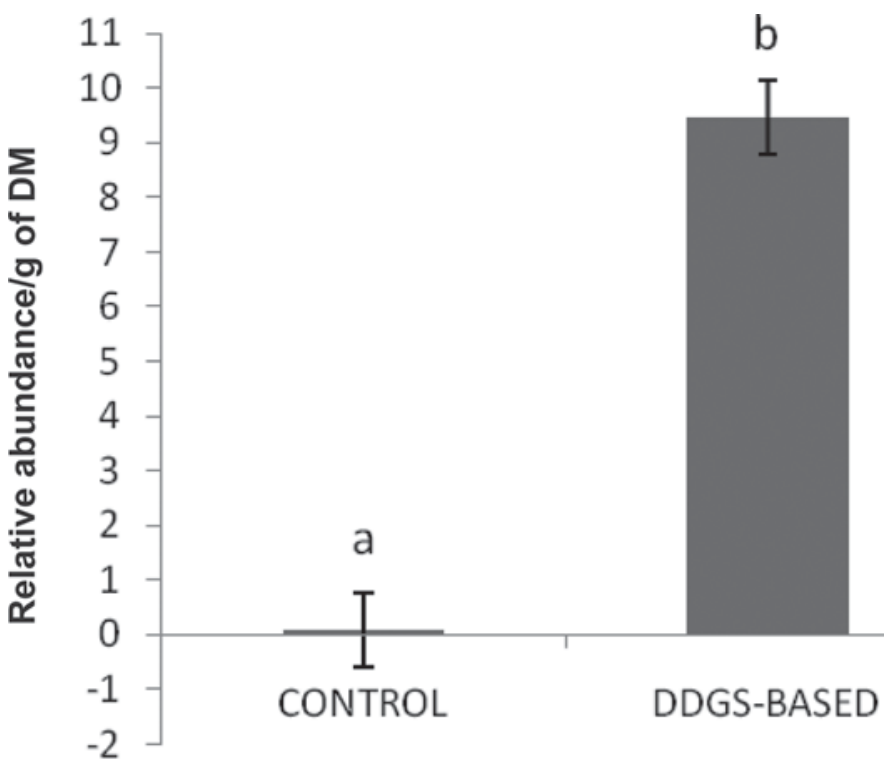

Treatment

Figure 1. Relative abundance obtained by real-time PCR of yeast DNA of omasal samples from cows being fed the control diet (no DDGS) versus a dried distillers grains and solubles (DDGS)-based diet (29.2\% DDGS). ${ }^{\mathrm{a}, \mathrm{b}}$ Estimates with different letters differ $(P<0.01)$.

DNA from yeast was observed at a much higher concentration in omasal samples when the DDGS-based diet was fed. The amount of yeast DNA originating from omasal samples was estimated as relative abundance of targeted yeast DNA/g of DM. As illustrated in Figure 1 , the estimates were different $(P<0.01)$ and were 9.46 and $0.091 \pm 0.67 / \mathrm{g}$ of DM for samples taken from cows fed the DDGS-based diet and the control diet, respectively. The effect of day on the abundance of yeast DNA was not significant $(P=0.54)$. Specifically, estimates were 5.08 and $4.48 \pm 0.68 / \mathrm{g}$ of $\mathrm{DM}$ for $\mathrm{d} 1$ and $\mathrm{d} 2$, respectively. In addition, the diurnal variation of yeast DNA relative abundance was not significant $(P$ $=0.35$ ): estimates were 4.32 and $5.24 \pm 0.68 / \mathrm{g}$ of $\mathrm{DM}$ for samples taken at $0400 \mathrm{~h}$ and $1600 \mathrm{~h}$, respectively. Furthermore, the estimated relative abundance of yeast DNA was $33.87 \pm 0.72 / \mathrm{g}$ of DM, $13.55 \pm 1.98 / \mathrm{g}$ of DM, and $0.0016 \pm 0.0006 / \mathrm{g}$ of DM for DDGS, DDGS-based diet, and control diet, respectively.

Total bacterial DNA was also measured in the omasal samples. All DNA samples were run in the same plate and a nontemplate control was included. Three sets of curves originated because each sample was subjected to 10-fold serial dilutions a total of 3 times. The first amplification curve crossed the threshold at approximately 19 cycles compared with the first CT observed in yeast DNA, which was approximately 29 when cows were fed DDGS. Total bacterial DNA originating from omasal samples was also estimated as relative abundance of 
targeted bacterial DNA per gram of DM. When the DDGS-based diet was fed, the relative abundance of total bacterial DNA tended to increase $(P=0.08)$ from 610 to $626 \pm 3.82 / \mathrm{g}$ of DM. It is important to note that the relative abundance of yeast DNA was small compared with the relative abundance of bacterial DNA. Assuming that bacteria account for the majority of microbial DNA (Sylvester et al., 2005), these observations suggest that yeast DNA does not represent a significant proportion of total microbial DNA in the omasal samples. In addition, it should be noted that this estimate simply represents a measure of DNA, and it is not known if these cells remain viable.

The results obtained in the experiment suggest that a portion of yeast DNA contained in DDGS is not degraded in the rumen. However, when total purines were measured from omasal samples, estimates were not different $(P=0.80)$ and were 7.45 and $7.39 \pm 0.2 \mathrm{mg} / \mathrm{g}$ of DM for samples originating from cows being fed the DDGS-based diet and the control diet, respectively. In the current experiment, the difference of total purines between treatments was small, suggesting that the contribution of yeast to total purines is minimal and of little practical importance to consider when estimating MCP. However, we also suggest real-time PCR as a viable approach to estimate MCP flow (Sylvester et al., 2005). This enables a longer term research focus using real-time PCR to study the relative contribution of bacteria, protozoa, and even small amounts of yeast to total MCP. With this approach, it is possible to do so because a segment of DNA unique to the type of microorganisms of interest is used as a marker. In the current experiment, we targeted yeast and bacterial DNA. However, previous research has demonstrated that the real-time PCR approach may be applied to detect and quantify other types of ruminal microbial populations such as protozoa (Sylvester et al., 2005). Furthermore, the approach that we want to apply with real-time PCR to measure MCP is similar to that of purine analysis; however, we measure DNA rather than purines as microbial markers. Perhaps more importantly, separate estimates of bacteria, protozoa, and yeast may be obtained.
Together, these findings indicate that when DDGS are fed to dairy cows the proportion of yeast DNA passing through the omasum is small compared with that of bacterial DNA. Furthermore, yeast DNA does not significantly alter the amount of total purines in digesta; therefore, the estimation of MCP is unlikely to be overestimated due to the presence of yeast cells contained in DDGS included in dairy rations.

\section{REFERENCES}

AOAC. 2000. Official Methods of Analysis. 17th ed. Association of Official Analytical Chemists, Arlington, VA.

Huhtanen, P., P. G. Brotz, and L. D. Satter. 1997. Omasal sampling technique for assessing fermentative digestion in the forestomach of dairy cows. J. Anim. Sci. 75:1380-1392.

Lapierre, H., D. Pacheco, R. Berthiaume, D. R. Ouellet, C. G. Schwab, P. Dubreuil, G. Holtrop, and G. E. Lobley. 2006. What is the true supply of amino acids for a dairy cow? J. Dairy Sci. 89(E Suppl.):E1-E14.

McAllan, A. B., and R. H. Smith. 1969. Nucleic acid metabolism in the ruminant: Determination of nucleic acids in digesta. Br. J. Nutr. 23:671-682.

Nadkarni, M. A., F. E. Martin, N. A. Jacques, and N. Hunter. 2002. Determination of bacterial load by real-time PCR using a broadrange (universal) probe and primers set. Microbiology 148:257266.

Obispo, N. E., and B. A. Dehority. 1999. Feasibility of using total purines as a marker for ruminal bacteria. J. Anim. Sci. 77:30843095.

SAS Institute. 2004. SAS/STAT User's Guide. Version 9.1. SAS Institute Inc., Cary, NC.

Sylvester, J. T., S. K. R. Karnati, Z. Yu, C. J. Newbold, and J. L. Firkins. 2005. Evaluation of a real-time PCR assay quantifying the ruminal pool size and duodenal flow of protozoal nitrogen. J. Dairy Sci. 88:2083-2095.

Weller, R. A., F. Gray, and A. Pilgrim. 1958. The conversion of plant nitrogen to microbial nitrogen in the rumen of the sheep. Br. J. Nutr. 12:421-429.

Wellinghausen, N., C. Frost, and R. Marre. 2001. Detection of legionellae in hospital water samples by quantitative real-time light cycler PCR. Appl. Environ. Microbiol. 67:3985-3993.

Yu, Y., C. Lee, K. Kim, and S. Hwang. 2005. Group-specific primer and probe sets to detect methanogenic communities using quantitative real-time polymerase chain reaction. Biotechnol. Bioeng. 89:670-679.

Yu, Z., and M. Morrison. 2004. Improved extraction of PCR-quality community DNA from digesta and fecal samples. Biotechniques $36: 808-812$.

Zinn, A. R., and F. N. Owens. 1986. A rapid procedure for purine measurement and its use for estimating net ruminal protein synthesis. Can. J. Anim. Sci. 66:157-166. 